\title{
ABSTRACTS OF COMMUNICATIONS
}

\author{
Four Hundred and Seventh Scientific Meeting \\ Physiology Lecture Theatre, Guy's Hospital Medical School, London \\ 14 DECEMBER 1984
}

POWERS HILARY J. A role for riboflavin in iron absorption?

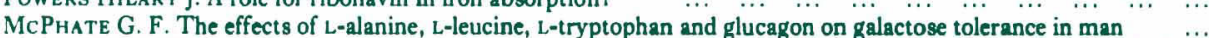

Pikaar N. A., Wedel M., van Dokkum W. \& Hermus R. J. J. The influence of the type of starch and of the incorporation of soluble dietary fibre in breakfast and lunch on the levels of glucose, insulin and C-peptide in plasma

Pacy P. J., Dodson P. M., Webster J. \& TAylor K. G. Effect of a high-fibre, low-fat and low-8odium diet on white European and black West Indian type II diabetic patients with mild hypertension

Dodson P. M., PACY P. J., COX E. V. \& TAYLOR K. G. Four year follow-up treatment of essential hypertension with a high-fibre, low-fat and low-sodium dietary regimen

Wan JeNNifer, Grimble R. F. \& Gore M. Decreased protein synthesis in skin, muscle and bone after interleukin 8 production by Escherichia coli endotoxin in rats

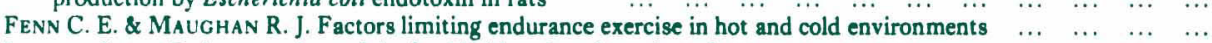

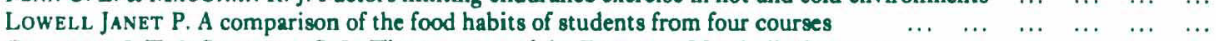

CAmpbell I. T. \& Snowdon S. L. The accuracy of the Engstrom Metabolic Computer $\ldots \ldots \ldots l l$
Noble R. C., Lonsdale F., Connor K. \& Brown D. Effects of parental age and lipid metabolism in the chick embryo

BRYAN LiNDA, BUTtERY P. J. \& Fisher C. The relationship between fractional growth rate and fractional rate of $\begin{array}{lllllllllll}\text { protein syn thesis within a population of growing broilers } & \ldots & \ldots & \ldots & \ldots & \ldots & \ldots & \ldots & \ldots & \ldots & \ldots\end{array}$

VINCENT R. \& LINDSAY D. B. Effect of pregnancy and lactation on muscle protein metabolism in sheep $\begin{array}{ccccc}\cdots & \ldots & \ldots\end{array}$

Peirce Paula, Jackson M., Tomkins A. \& Millward D. J. Zinc is highly conserved in the severely Zn-deficient rat

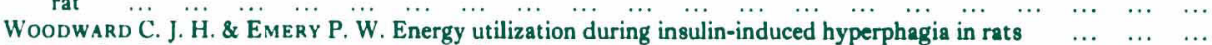

Falcou R., Rozen R. \& Apfelbaum M. Effect of a cafeteria diet on the metabolism of brown adipose tissue in young and old rats

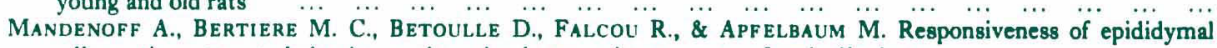

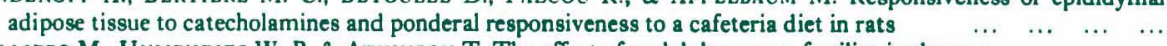

Phillippo M., Humphries W. R. \& Atkinson T. The effect of molybdenum on fertility in the cow $\ldots \ldots \ldots$

PARTRIDGE I. G., SimON O. \& BERGNER H. Dietary and endogenous nitrogen in different regions of the digestive

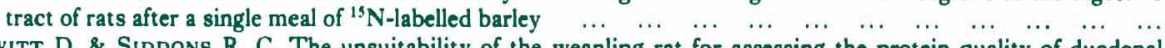

HEwitT D. \& SidDons R. C. The unsuitability of the weanling rat for assessing the protein quality of duodenal digesta from lucerne (Medicago sativa) silage-fed sheep $\quad \begin{array}{lllllllllllll} & \ldots & \ldots & \ldots & \ldots & \ldots & \ldots & \ldots & \ldots & \ldots & \ldots\end{array}$

Newbold C. J., Chamberlain D. G. \& Williams A. G. Ruminal metabolism of lactic acid in sheep receiving a

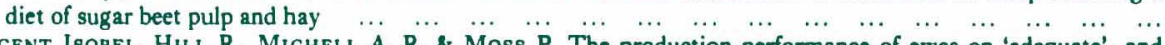

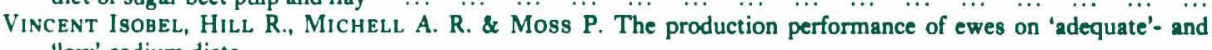

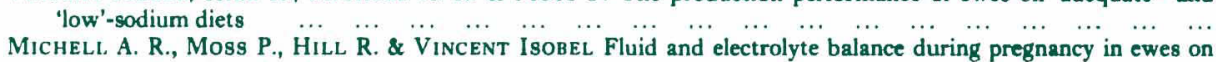

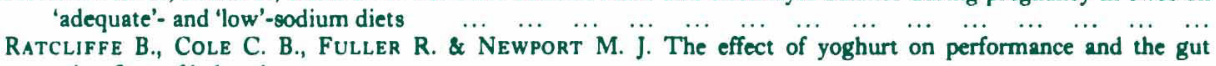
microflora of baby pigs

$66 \mathrm{~A}$

$67 \mathrm{~A}$

$69 A$

$70 A$

$71 \mathrm{~A}$

$72 \mathrm{~A}$

$73 \mathrm{~A}$

$74 \mathrm{~A}$

$75^{\mathrm{A}}$

$76 \mathrm{~A}$

$77^{\mathrm{A}}$

$78 \mathrm{~A}$

79 A

$80 A$

$8 \mathrm{I} A$

$82 \mathrm{~A}$

${ }_{83 A}$

$84 \mathrm{~A}$

${ }_{85} \mathrm{~A}$

$86 \mathrm{~A}$

$87 \mathrm{~A}$

88A 


\section{Proceedings of the Nutrition Society}

\section{CONTENTS OF VOL. 44 , No. 2 , JULY 1985}

\section{SYMPOSIUM PROCEEDINGS}

Three Hundred and Ninety-ninth Scientific Meeting

Medical and Biological Sciences Building, University of Southampton

$\mathrm{I}_{2} / \mathrm{I}_{3} \mathrm{JULY} \mathrm{I}_{9} 84$

NUTRITIONAL ASPECTS OF MEMBRANE STRUCTURE AND FUNCTION

Chairmen: T. G. TAYLOR, University of Southampton, Southampton

M. A. CRAWFord, Institute of Zoology, London

M. I. GurR, National Institute for Research in Dairying, Reading

LEE A. G. Some principles of membrane structure

Houslay Miles D. Regulation of adenylate cyclase $\left(E C_{4}\right.$.6.1.1 ) activity by its lipid environment $\quad \ldots \quad \ldots \quad \ldots \quad$ I57-165

HaWthorne J. N. Inositol phospholipid and phosphatidic acid metabolism in response to membrane receptor activation

$\begin{array}{lllllllllllllll}\text { FrASER D. R. Trace elements and vitamins in membrane function } & \ldots & \ldots & \ldots & \ldots & \ldots & \ldots & \ldots & \ldots & \ldots & \ldots \\ \end{array}$

YоRк DAVID A. Alterations in membrane function, organization and composition in the obese $a b / o b$ mouse $\quad \ldots \quad \ldots \quad$ I $\quad \ldots 9-200$

Smith A. D., Conroy D. M., Belin J. \& Stubbs C. D. Membrane lipid modification and immune function $\quad \ldots \quad \ldots \quad 20 \mathrm{I}-209$

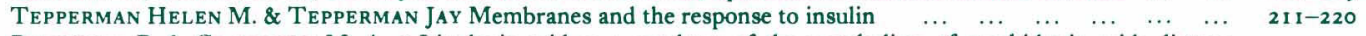

Budowski P. \& CRAWFord M. A. $\alpha$-Linolenic acid as a regulator of the metabolism of arachidonic acid: dietary

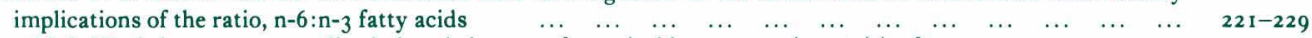

$\begin{array}{llllllll}\text { GURR M. I. Workshop report: are diet-induced changes of practical importance in nutrition? } & \ldots & \ldots & \ldots & \ldots & 23 \mathbf{I}-233\end{array}$

Four Hundred and First Scientific Meeting

Martin Hall Lecture Theatre, University of Loughborough

II 12 SEPTEMBER 1984

EXERCISE, A STIMULUS FOR METABOLISM AND A CHALLENGE TO NUTRITION

Chairmen: P. O. ÄSTRAND, Karolinska Institute, University of Stockholm

J. P. CROWDY, London

PERRY S. V. The biochemistry and physiology of the muscle cell Williams ClYDE Nutritional aspects of exercise-induced fatigue Galbo HenRik The hormonal response to exercise $\ldots \ldots$
Snow D. H. The horse and dog, elite athletes - why and how?

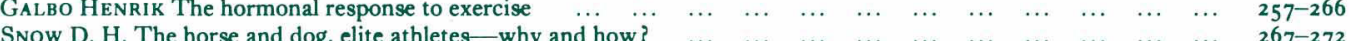

Bruce A., Еквцом B. \& NILsson I. The effect of vitamin and mineral supplements and health foods on physical

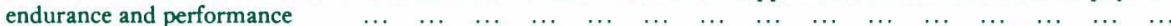

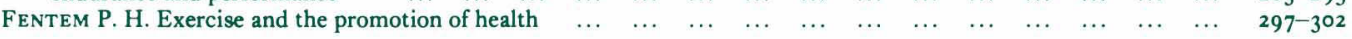

Four Hundred and Third Scientific Meeting

One Hundred and Fifty-seventh Scottish Meeting

Cowan House, Pollock Halls, Holyrood Park Road, Edinburgh

25/26 SEPTEMBER 1984

FOOD INTAKE, AND ITS CONTROL BY FARM ANIMALS

Chairman: P. N. WiLson, School of Agriculture, Edinburgh

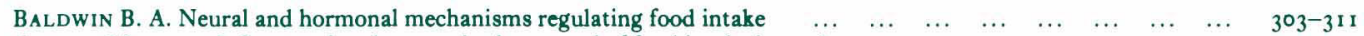
GentLe Michael J. Sensory involvement in the control of food intake in poultry $\quad \begin{array}{lllllllllll}\ldots & \ldots & \ldots & \ldots & \ldots & \ldots & \ldots & 3 \mathrm{I} & \mathbf{3}-3^{2} \mathrm{I}\end{array}$

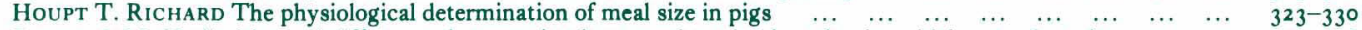
Forbes J. M. Similarities and differences between intake control mechanisms in pigs, chickens and ruminants $\quad \ldots \quad 33 \mathrm{I}-33^{8}$

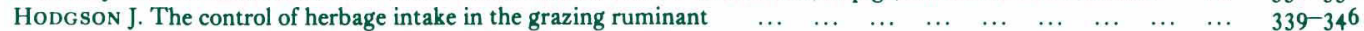

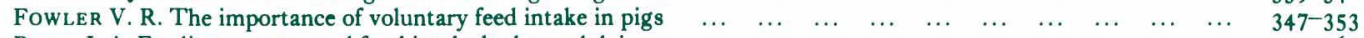

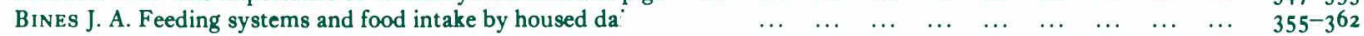

[Continued on p. iii of wrapper]

(C) The Nutrition Society, 1985

CAMBRIDGE UNIVERSITY PRESS

The Pitt Building, Trumpington Street, Cambridge $\mathrm{CB}_{2} \times \mathrm{RP}$

32 East 57 th Street, New York, NY 10022, USA

io Stamford Road, Oakleigh, Melbourne 3166, Australia 